Note

\title{
Child Labour - Facts and Fiction
}

\section{M.A.K. Chaudhry}

Child labour exists throughout the third world including Pakistan. For some unknown reason, the Western Press has chosen to single out Pakistan to decry the system. The May 1997 issue of the Readers' Digest carried a particularly vicious article entitled 'No Life for a Child' giving harrowing tales of beatings and other forms of coercion to make little children in Pakistan to work in factories. Advantage is taken of the fact that there has been no census in the country for two decades to bloat the figures of child labour. One estimate going the rounds is 15 million. But the more popular figure is 8 million which both UNICEF and SAARC have adopted. ILO produced a figure of 6.3 million till, in 1996 it sponsored a survey which turned up the figure of 3.3 million. In a country with a population of 132 million, every man, woman and child of which is under a debt burden of about Rs 13,021 per annum the figure of 3.3 million labouring children should not take anyone by surprise. Not that this is any justification for child labour.

What is generally stated and believed to be an incentive for child labour is one particular industry, i.e. carpet weaving in which the nimble fingers of children tie better knots in handmade carpets. A prestigious social sector NGO, namely Friedrick Ebert Stiftung has blown this myth in its AprilSeptember 1996 issue of its journal, which, to quote says 'Quite often productivity and in particular the quality of carpets are linked with the use of child labour. This is certainly more a myth than a reality and the nimble finger argument has no real base. Factually, the quality of carpets is associated with the expertise a weaver acquires over the years of weaving'. The article goes on to outline the programme of eradication of child labour from the carpet industry in Pakistan in which the government, the manufacturers and the buyers are collaborating with great success. But this aspect of the problem has been conveniently ignored by the author of the article in the Readers' Digest referred to earlier. On the contrary, this article and other media have deliberately tried to foster the impression that authorities and society in Pakistan are entirely apathetic to the problem of child labour.

Child 1abour exists in Pakistan for a variety of reasons, the chief among them being poverty, insufficient schooling facilities, vast number of drop outs from primary and middle schools, under employment of parents and their abysmally low wages. These factors explain its prevalence, 
notwithstanding there is a keen awareness of the evil of child labour in the community, spurred no doubt by writings first in Pakistan and later abroad. Steps are hence underway in both the formal and informal sectors, to contain it as a first step but to work gradually towards its total eradication. In any case, there is no dearth of laws forbidding child labour, implementation of which has to date been lax by design. The Constitution of Pakistan prohibits the employment of children under the age of fourteen years in any factory, mine or other hazardous form of employment. The Mines Act of 1923, the Factories Act of 1924, the Road Transport Workers Ordinance of 1961, the West Pakistan Shops and Establishments Ordinance 1969, all forbid the employment of children under the age of fourteen years in hazardous undertakings. Two new enactments namely the Employment of Children Act 1991 and the Bonded Labour System (Abolition) Act 1992 have been added to the Statute Book to further re-enforce the programme of elimination of child labour. A child labour cell has been created in the Ministry of Labour to watch over the implementation of these laws. Pakistan is a signatory to the International Programme for the Elimination of Child Labour (IPEC) of the ILO and is seriously following it up.

Interestingly, a recent $\mathrm{I} 1 \mathrm{O}$ sponsored seminar in Islamabad adopted a pragmatic view of the problem and held, very candidly, total eradication of child labour in pakistan in the short run would not be practicable, but if children could be retrieved from hazardous and exploitative labour it would be a tremendous step forward. For purposes of definition, any occupation which could be harmful to the child's development is hazardous labour. For example, lifting weights beyond the physical capacity of a child, exposure to dangerous work implements, an environment where accidents are frequent, lack of respect for the dignity of the child, abusive language, etc. will all fall in this category. Any forms of labour which exploits the child economically such as less wages for equal work, lack of breaks during work, poor work environment, are all forms of exploitative labour.

In 1995, the Ministry of Social Welfare, Government of Pakistan took the initiative of launching a tentative programme of retrieval of children from hazardous and exploitative labour and selected the Pakistan Bait ul Mal (PBM) for the implementation. I was associated with this programme and would like here to outline it briefly.

Raised under a Statute and funded by the Government of Pakistan, PBM has many programmes of assistance for indigent and needy citizens. Their motto is generous help to the disabled, old, infirm and indigent citizens who are permanently or temporarily incapacitated from earning their livelihood, to make life comfortable for them. To the able-bodied and 
unskilled, a skill and seed money to start a trade. To the able bodied, skilled but unemployed, seed money to launch himself/herself. Generous help to needy students. PBM has entered the field of child labour in 1995 by opening a chain of thirty five schools as a pilot project.

The first hurdle in retrieval of children was the employer who was loath to let go cheap labour. Appeal was made to his sense of duty towards the flower of the nation.

At the end of the discourse, a veiled threat of enforcement of law was added. It worked. The second hurdle was the parents who had misgivings about the project including the apprehension that the whole drama was for kidnapping the children to be sold abroad. They also dreaded the loss of wages of their children were they to be taken off the labour market. Their fears were allayed with the involvement of the local community. The third hurdle was the children themselves for they felt their independence was being denied to them. Hand-picked and specially trained teachers managed to 'tame' them in no time.

As a policy it was decided not to confine the effort to a halfway measure such as providing a few study hours to a working child, but to aim at his total withdrawal from labour. Children, both boys and girls, working in hazardous and exploitative labour such as brick kilns, chemical factories, textiles, sports goods manufacture, surgical instruments manufacture, carpet weaving and boys working in restaurants from the crack of dawn till late at night, were to be withdrawn. The age cohort of eight to fourteen years was selected. Education, it was decided, should not be confined to mere literacy or even primary level but taken to the middle level, i.e. eighth class Board examination. It was also decided to add to scholastic education a modicum of technical training. Allama Iqbal Open university gave generous assistance in devising a syllabus which telescoped eight years of ordinary scholarship into four years by cutting out long and short vacations and other unnecessary holidays, having a full school day from 9 am to $4 \mathrm{pm}$ and above all, by carefully selecting qualified and motivated teachers. The long day at school also eliminated the temptation of doing a quick shift in a factory for extra wages. This does not mean, however, that the children were force-fed the syllabus. On the contrary, there are extra-curricula activities such as public speaking contests, dramatics, indoor and outdoor games and educational exercises. Guest speakers are invited from time to time.

Many children were found to be stunted, underweight and ill without the employer or even parents knowing about it. So complete health cover was provided. Children eat a wholesome midday meal which includes 
a pint carton of milk and multi-vitamins. Teachers eat with them to teach them good eating manners. The School maintains two files on every student, one for his academic record and the other on his health. The School expects them to show positive improvement in both.

Children wear distinctive uniforms and teachers wear gowns in classrooms which makes for a sober academic atmosphere. Teachers are expected to groom the children into little ladies and gentlemen. Children receive Rs 150 per month for the upkeep of uniforms and transport. Parents receive Rs 250 per month as compensation for loss of wages of the children.

To begin with each school has sixty children in two classes of thirty each. Every year thirty students will be added to each school. Simultaneously, PBM is ready to multiply the number of schools. On certification of four years in school, students will go to a technical training facility for six months training in a marketable skill. It is hoped that with middle level education and technical training, a boy or a girl at age fourteen and above (legally permissible age to work) will have better value in the labour market. Children who show promise will continue with their education under another PBM scheme.

There is a parent-teacher meeting once a month. The occasion is used to create awareness in them. These schools are thus acting as agents of change in the families and the response is remarkable. So is the progress of children in their studies and health in addition to learning good manners and gaining confidence in expressing themselves.

All this has happened in a span of two and a half years but it has given PBM valuable experience in enabling it to undertake expansion of the project. The local communities which are involved in the management of the schools are growing fond of their tasks and giving it more and more time and attention. As at present, a turn out of five thousand students every is small change, in the context of a backlog of 3.3 million labouring children. But as trail blazers, PBM has set a pattern and many Ngos are entering into this field now. Public sector initiatives of this kind start with much fanfare but soon fall into the clutches of the bureaucratic routine, showing indifferent results. Some are simply still born. But the PBM effort is consistent as is evident from the interest shown by several international agencies such as the ILO, UNICEF and others. Members of the diplomatic corps have asked to be invited to visit these schools and those who did go to see them came back thoroughly impressed. 